\title{
Tillering Dynamics and Productivity of BRRI dhan44 as Influenced by Spacing and Nitrogen Management Technique
}

\author{
Md. HARUNUR R ASHID* AND MD. AKHTER Hossain KHAN \\ Rice Farming Systems Division, Bangladesh Rice Research Institute, Gazipur, Bangladesh
}

Received 20 September 2004; received in revised form 18 June 2006; accepted 22 June 2006

\begin{abstract}
The experiment was conducted at the Bangladesh Rice Research Institute farm to study the tillering dynamics and the productivity of the variety, BRRI dhan44 under four spacing $(20 \mathrm{~cm} \times 15 \mathrm{~cm}, 25$ $\mathrm{cm} \times 15 \mathrm{~cm}, 20 \mathrm{~cm} \times 20 \mathrm{~cm}$ and $25 \mathrm{~cm} \times 25 \mathrm{~cm})$ and varying levels $\left(0,60,80,100 \mathrm{~kg} \mathrm{~N} \mathrm{ha}{ }^{-1}\right)$ and technique (Leaf Color Chart based $\mathrm{N}$ ) of $\mathrm{N}$. The wider spacing produced higher number of tillers at maximum tillering stage which was not realized in to number of on ear bearing tiller $\mathrm{m}^{2}$. Grain yield was not influenced by spacing. A similar grain yield of BRRI dhan44 at a wider spacing of $25 \mathrm{~cm} \times 25$ $\mathrm{cm}$ indicated its suitability where wider spacing is practiced. The higher amount of added $N$ produced higher non bearing tillers hill ${ }^{-1}$. Grain yield obtained from $80,100 \mathrm{~kg} \mathrm{~N} \mathrm{ha}^{-1}$ and leaf color chart (LCCN) was comparable.
\end{abstract}

Key words:Spacing, nitrogen management, tillering dynamics, productivity, rice.

\section{INTRODUCTION}

The tidal non saline wetlands cover about 1.9 million hectares under different land types in southern districts of Bangladesh. About 90 per cent of this area is under medium highland and highland. The area is inundated by tide surge twice a day with varying depths. The predominant cropping systems of this area are T. Aus-T. Aman and Fallow-T. Aman. Under a participatory research and development activities of Bangladesh Rice Research Institute (BRRI), Department of Agricultural Extension and farmers, the newly released variety BRRI dhan44 was identified most suitable for single T. Aman cropping system for its high yield. Increasing demand was noticed among the farmers and extension providers for adopting and rapid scaling up of this material (Khan et al., 2003).

Nitrogen is one of the major nutrient elements and widely used in rice cultivation. Its requirement in rice varies from variety to variety even in the same season depending on growth duration, yield potential and nitrogen recovery efficiency (BRRI, 1998; BRRI, 1999b). The efficiency of added nitrogen in wetland rice soil is very low, ranging from 30-40 \% and even less in many cases (Rashid et al., 1996). To increase this efficiency of $\mathrm{N}$ several $\mathrm{N}$ management techniques have been recommended. The real time $\mathrm{N}$ management through Leaf Color Chart (LCC) is one of the most effective recommendations given by IRRI (1999). It is a plant based $\mathrm{N}$ management technique where $\mathrm{N}$ is top dressed when rice plant requires the same. Thus the time of $\mathrm{N}$ splitting and the number of splitting vary from variety to variety, season to season and location to location depending on inherent $\mathrm{N}$ supplying capacity of soils.

\footnotetext{
* Corresponding author: SSO, RFSD, BRRI, Gazipur-1701. E-mail: hrashid67@yahoo.com

(C) 2006, School of Agriculture and Rural Development, Bangladesh Open University. All rights reserved.
} 
Elahi et al. (2001) reported that farmers of tidal non saline areas grow rice with wider spacing. Wider spacing gave better grain filling due to lesser competition among the plants for light, space water and nutrition (Saha and Saha, 1998). But its reflection on grain yield is important. A few researchers found higher grain yield up to certain level of wider spacings (Shukla et al., 1996) and others reported the higher grain yield at closer spacings (Paraye et al., 1996). BRRI (1998) observed that rice variety requires different amount of $\mathrm{N}$ at different plant populations. On the contrary, Ryong et al. (1998) reported that yield of some varieties increased with increasing $\mathrm{N}$ rate but was not significantly affected by spacing, whereas yield of some other variety was not significantly affected by $\mathrm{N}$ but was highest from a closer spacing.

Efficient nitrogen management along with appropriate plant density is an important area of examination for the newly released variety BRRI dhan44. With this view in mind, this experiment was conducted to determine the appropriate spacing and nitrogen management for producing higher ear bearing tillers and grain yield of the tested variety.

\section{MATERIALS AND METHODS}

The experiment was conducted at the Bangladesh Rice research Institute (BRRI) farm, during T. Aman season, 2002. The soil of the experimental field was silty clay loam. Four spacings, $20 \mathrm{~cm} x$ $15 \mathrm{~cm}, 25 \mathrm{~cm} \times 15 \mathrm{~cm}, 20 \mathrm{~cm} \times 20 \mathrm{~cm}$ and $25 \mathrm{~cm} \times 25 \mathrm{~cm}$ and four levels of nitrogen, $0,60,80$ and $100 \mathrm{~kg} \mathrm{~N} \mathrm{ha}^{-1}$ along with LCC-based nitrogen management technique were tested. Phosphate, potash and sulphur were applied at the rate of 20,35 and $11 \mathrm{~kg} \mathrm{ha}^{-1}$ as triple super phosphate, muriate of potash and gypsum, respectively, to all plots at final land preparation as per BRRl's recommendation for BRRI dhan31 (BRRI, 1999a) having similar growth duration. Nitrogen as urea was applied in three equal splits at 15, 30 and 45 days after transplanting (DAT) in case of three levels of nitrogen treatment except control $(0 \mathrm{~N})$. In LCC-based $\mathrm{N}$ management, leaf color of the top most youngest fully expanded leaves of ten randomly selected representative hills per plot was matched with LCC at 7 day intervals starting from 15 DAT to booting stage. When the average value of LCC fell below the critical value of $4, \mathrm{~N}$ was applied as per recommendation of IRRI (1999). Nitrogen was applied as urea in the LCC treatment at the rate of $25 \mathrm{~kg} \mathrm{~N} \mathrm{ha}^{-1}$ per split at 15, 29, 42 and 56 DAT.

The experiment was laid out in a split-plot design with three replications assigning spacing in the main plots and nitrogen treatments in the sub plots. Twenty eight day old seedlings were transplanted with 2-3 seedlings hill ${ }^{-1}$ on 24 July 2002 following different treatment spacings. Intercultural operations including weeding and pest management were done as per requirement.

Three spots were selected diagonally in each unit plot. A total of 12 hills per plot (two hill $x$ two hill sampling unit) was selected from the predetermined spots and the number of tillers were counted at 10 day intervals starting from 20 DAT to heading stage and the final count was done at crop maturity. For yield components, 20 hills per plot were selected and counted the number of panicles per hill and made average which was considered as panicles hill ${ }^{-1}$. Finally, three hills having average or around average number of panicles were selected. Each panicle of three hills was weighed and made the average. Then three panicles with average or around average weight were selected from each unit plot. Filled grains panicle ${ }^{-1}$ and 1000 grain weight were calculated from those three panicles. The effectivity index of tillers was calculated from the selected 12 hills per plot in accordance with Singh et al. (1988) as follows.

Effectivity index of tillers $=\frac{\text { No. of ear bearing tillers } / \text { hill }}{\text { Total no. of tillers/hill }} \times 100$.

At maturity, a sample of $6 \mathrm{~m}^{2}$ area for each plot was harvested for grain yield. The grain yield was adjusted to $14 \%$ moisture content. Data were analyzed statistically and mean differences were compared by Duncan's Multiple Range Test (DMRT).

\section{RESULTS AND DISCUSSION}

\section{Tillering Dynamics}

The tiller number hill ${ }^{-1}$ differed significantly due to spacing and nitrogen level including the LCC technique over the crop growing season except at initial stage, 20 DAT (Table 1 and 2). The 
highest number of tillers hill ${ }^{-1}$ was recorded at $25 \mathrm{~cm} \times 25 \mathrm{~cm}$ spacing and decreased with decreasing spacing (Table 1). A similar finding was also reported by Yang et al. (2000), Rahman and Barua (1998) and Srivastava et al. (1999).

Table 1. Number of tiller per hill at different dates after transplanting (DAT) under different spacing

\begin{tabular}{lcccccc}
\hline \multirow{2}{*}{ Spacing } & \multicolumn{7}{c}{ Date after transplanting } \\
\cline { 2 - 7 } & 20 DAT & 30 DAT & 40 DAT & 50 DAT & 60 DAT & Maturity \\
\hline \hline $20 \mathrm{~cm} \times 15 \mathrm{~cm}$ & 7.32 & $11.91 \mathrm{~d}$ & $13.17 \mathrm{c}$ & $12.22 \mathrm{c}$ & $8.76 \mathrm{~d}$ & $7.99 \mathrm{~d}$ \\
$25 \mathrm{~cm} \times 15 \mathrm{~cm}$ & 7.23 & $12.92 \mathrm{c}$ & $15.43 \mathrm{~b}$ & $13.91 \mathrm{~b}$ & $9.97 \mathrm{c}$ & $8.81 \mathrm{c}$ \\
$20 \mathrm{~cm} \times 20 \mathrm{~cm}$ & 7.75 & $14.47 \mathrm{~b}$ & $15.75 \mathrm{~b}$ & $14.58 \mathrm{~b}$ & $10.98 \mathrm{~b}$ & $9.69 \mathrm{~b}$ \\
$25 \mathrm{~cm} \times 25 \mathrm{~cm}$ & 7.72 & $16.64 \mathrm{a}$ & $20.97 \mathrm{a}$ & $20.25 \mathrm{a}$ & $16.08 \mathrm{a}$ & $13.63 \mathrm{a}$ \\
\hline $\mathrm{CV}(\%)$ & 19.8 & 6.8 & 8.7 & 7.5 & 4.7 & 7.5 \\
\hline
\end{tabular}

In a column, means followed by common letter do not differ significantly at $5 \%$ level of DMRT

Up to 50 DAT, 80 and $100 \mathrm{~kg} \mathrm{~N}$ ha $^{-1}$ and LCC-based $\mathrm{N}$ management produced similar number of tillers hill ${ }^{-1}$ with an exception of $80 \mathrm{~kg} \mathrm{~N} \mathrm{ha}^{-1}$ at 50 DAT. At 60 DAT and at maturity all the tested $\mathrm{N}$ levels including the LCC treatment produced similar number of tillers hill ${ }^{-1}$ which was significantly higher than the control treatment. Irrespective of spacing and $\mathrm{N}$ level together with LCC technique, the higher number of tillers hill ${ }^{-1}$ was recorded at 40 DAT (Table 2). Results indicated that the maximum tillering stage of BRRI dhan44 might be at around 40 DAT.

Table 2. Number of tiller per hill at different dates after transplanting (DAT) under different nitrogen rate and technique

\begin{tabular}{lcccccc}
\hline \multirow{2}{*}{$\begin{array}{l}\text { Nitrogen rate and } \\
\text { technique }\end{array}$} & Date after transplanting \\
\cline { 2 - 7 } & 20 DAT & 30 DAT & 40 DAT & 50 DAT & 60 DAT & Maturity \\
\hline \hline $0 \mathrm{~kg} \mathrm{~N} \mathrm{ha}^{-1}$ & 7.02 & $12.27 \mathrm{c}$ & $14.08 \mathrm{c}$ & $12.64 \mathrm{~d}$ & $9.87 \mathrm{~b}$ & $9.18 \mathrm{~b}$ \\
$60 \mathrm{~kg} \mathrm{~N} \mathrm{ha}^{-1}$ & 7.31 & $13.47 \mathrm{~b}$ & $16.07 \mathrm{~b}$ & $14.49 \mathrm{c}$ & $11.51 \mathrm{a}$ & $10.09 \mathrm{a}$ \\
$80 \mathrm{~kg} \mathrm{~N} \mathrm{ha}^{-1}$ & 7.49 & $14.73 \mathrm{a}$ & $16.99 \mathrm{ab}$ & $15.14 \mathrm{~b}$ & $11.81 \mathrm{a}$ & $10.02 \mathrm{a}$ \\
$100 \mathrm{~kg} \mathrm{~N} \mathrm{ha}^{-1}$ & 7.67 & $14.90 \mathrm{a}$ & $17.51 \mathrm{a}$ & $16.83 \mathrm{a}$ & $11.78 \mathrm{a}$ & $10.33 \mathrm{a}$ \\
$\mathrm{LCC}-\mathrm{N}$ & 8.04 & $14.57 \mathrm{ab}$ & $16.99 \mathrm{ab}$ & $16.10 \mathrm{a}$ & $12.05 \mathrm{a}$ & $10.52 \mathrm{a}$ \\
\hline $\mathrm{CV}(\%)$ & 13.0 & 10.1 & 10.0 & 7.5 & 7.0 & 7.5 \\
\hline
\end{tabular}

In a column, means followed by common letter do not differ significantly at $5 \%$ level of DMRT

\section{Effectivity Index of Tillers}

The effectivity index of tillers (EIT) was found higher in $25 \mathrm{~cm} \times 25 \mathrm{~cm}(58.12 \%)$ which was comparable to $20 \mathrm{~cm} \times 20 \mathrm{~cm}(52.38 \%)$ and significantly higher than the closer spacing $(46.62 \%$ in $25 \mathrm{~cm} \times 15 \mathrm{~cm}$ and $50.63 \%$ in $20 \mathrm{~cm} \times 15 \mathrm{~cm}$ ) (Table 3). The EIT was found comparable up to $80 \mathrm{~kg} \mathrm{~N} \mathrm{ha}^{-1}$ and then decreased (Table 4). It indicated that the higher amount of added $\mathrm{N}$ in the conventional system produced higher non bearing tiller hill ${ }^{-1}$.

Table 3. Effectivity index of tillers, filled grain per panicle and 1000-grain weight under different spacing

\begin{tabular}{lccc}
\hline Spacing & Tiller effectivity index (\%) & Filled grain panicle ${ }^{-1}$ (No.) & 1000-grain weight $(\mathrm{g})$ \\
\hline \hline $20 \mathrm{~cm} \times 15 \mathrm{~cm}$ & $50.63 \mathrm{~b}$ & $97.6 \mathrm{~b}$ & 21.89 \\
$25 \mathrm{~cm} \times 15 \mathrm{~cm}$ & $46.62 \mathrm{bc}$ & $101.5 \mathrm{~b}$ & 21.91 \\
$20 \mathrm{~cm} \times 20 \mathrm{~cm}$ & $52.38 \mathrm{ab}$ & $104.1 \mathrm{ab}$ & 22.05 \\
$25 \mathrm{~cm} \times 25 \mathrm{~cm}$ & $58.12 \mathrm{a}$ & $109.6 \mathrm{a}$ & 22.19 \\
\hline $\mathrm{CV}(\%)$ & 16.0 & 8.6 & 1.2 \\
\hline
\end{tabular}

In a column, means followed by common letter do not differ significantly at $5 \%$ level of DMRT 


\section{Yield Components}

\section{Number of panicles per unit area}

Significant differences were found in number of panicles per unit area under different spacings. The closer spacings, $20 \mathrm{~cm} \times 15 \mathrm{~cm}$ and $25 \mathrm{~cm} \times 15 \mathrm{~cm}$ produced higher number of panicle $\mathrm{m}^{-2}$ (Fig.1). Although the EIT was found higher in wider spacing, the number of the panicles per unit area as deceased might be because of decreased plant population. Similar findings were also reported by Yang et al. (2000), Wang et al. (1999) and Rekhashri et al. (1997) where they observed that panicles $\mathrm{m}^{-2}$ increased at closer spacing. Added nitrogen at different levels gave significantly higher panicles $\mathrm{m}^{-2}$ compared to the control treatment (Fig. 2).

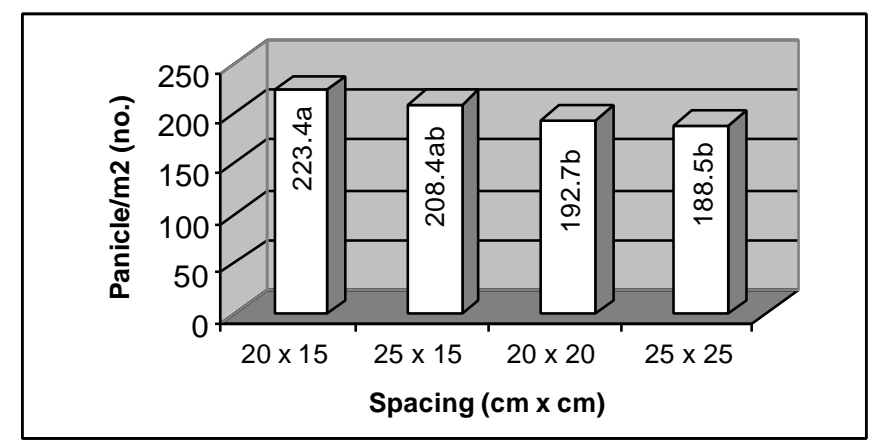

Fig. 1. Number of Panicle $\mathrm{m}^{-2}$ under different spacing

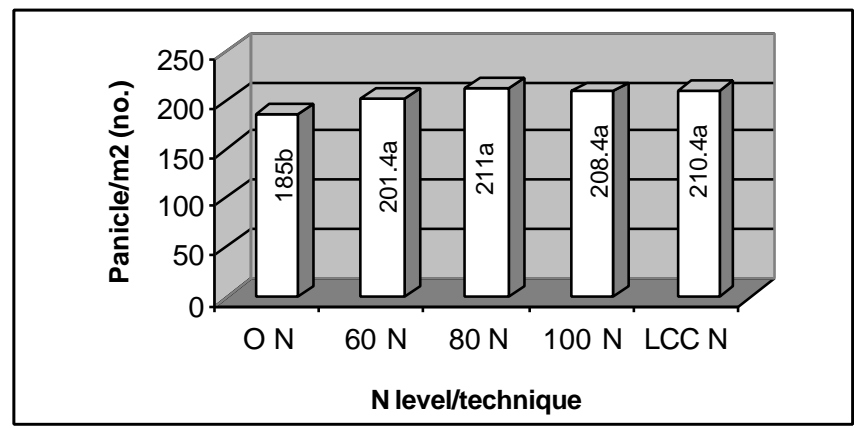

Fig. 2. Number of panicle $\mathrm{m}^{-2}$ under different $\mathrm{N}$ level and technique

\section{Number of filled grains per panicle}

Significantly higher filled grains panicle ${ }^{-1}$ was found at the wider spacing, $25 \mathrm{~cm} \times 25 \mathrm{~cm}(109.6)$ which was comparable to $20 \mathrm{~cm} \times 20 \mathrm{~cm}$ (104.1). The filled grains panicle ${ }^{-1}$ decreased at closer spacing (Table 3). This finding was in agreement with the finding of Wang et al. (1999), Rahman and Barua (1998) and Rekhashri et al. (1997). Added N produced higher number of filled grains panicle ${ }^{-1}$ than the control $\mathrm{N}$ treatment. However, all the $\mathrm{N}$ treatments produced comparable filled grains panicle ${ }^{-1}$ (Table 4).

\section{0-grain weight}

1000 -grain weight was not affected by spacing but there is a tendency of increasing 1000- grain weight with increased spacing (Table 3). On the other hand, grain weight increased with the increase in $\mathrm{N}$ level up to $80 \mathrm{~kg} \mathrm{~N} \mathrm{ha}^{-1}$. The LCC- based $\mathrm{N}$ management and $100 \mathrm{~kg} \mathrm{~N} \mathrm{ha}^{-1}$ produced the grain of similar weight (Table 4). This finding was in agreement with the finding of Maske et al. (1997). 
Table 4. Effectivity index of tillers, filled grain per panicle and 1000-grain weight under different nitrogen rate and technique

\begin{tabular}{lccc}
\hline Spacing & Tiller effectivity index (\%) & Filled grain panicle ${ }^{-1}$ (No.) & 1000-grain weight (g) \\
\hline \hline $0 \mathrm{~kg} \mathrm{~N} \mathrm{ha}^{-1}$ & $54.26 \mathrm{a}$ & $92.5 \mathrm{~b}$ & $19.91 \mathrm{~d}$ \\
$60 \mathrm{~kg} \mathrm{~N} \mathrm{ha}^{-1}$ & $51.99 \mathrm{ab}$ & $104.6 \mathrm{a}$ & $21.31 \mathrm{c}$ \\
$80 \mathrm{~kg} \mathrm{~N} \mathrm{ha}^{-1}$ & $52.41 \mathrm{ab}$ & $105.2 \mathrm{a}$ & $22.67 \mathrm{~b}$ \\
$100 \mathrm{~kg} \mathrm{~N} \mathrm{ha}^{-1}$ & $49.76 \mathrm{bc}$ & $105.7 \mathrm{a}$ & $23.07 \mathrm{a}$ \\
$\mathrm{LCC}-\mathrm{N}$ & $51.26 \mathrm{~b}$ & $108.0 \mathrm{a}$ & $23.11 \mathrm{a}$ \\
\hline $\mathrm{CV}(\%)$ & 5.5 & 9.7 & 1.4 \\
\hline
\end{tabular}

In a column, means followed by common letter do not differ significantly at $5 \%$ level of DMRT

\section{Grain Yield}

The grain yield ranged from 4.11 to $4.43 \mathrm{t} \mathrm{ha}^{-1}$ and was not affected by spacing (Fig. 3). It might be due to production of higher number of panicles per unit area at closer spacing and higher filled grains panicle ${ }^{-1}$ at wider spacing. Lourduraj and Rajagopal (1999) also reported that wider spacing did not affect rice grain yield. Wider spacing with similar yield indicated the suitability of the variety, BRRI dhan44 for existing wider spacing practiced in non-saline tidal sub-ecosystem.

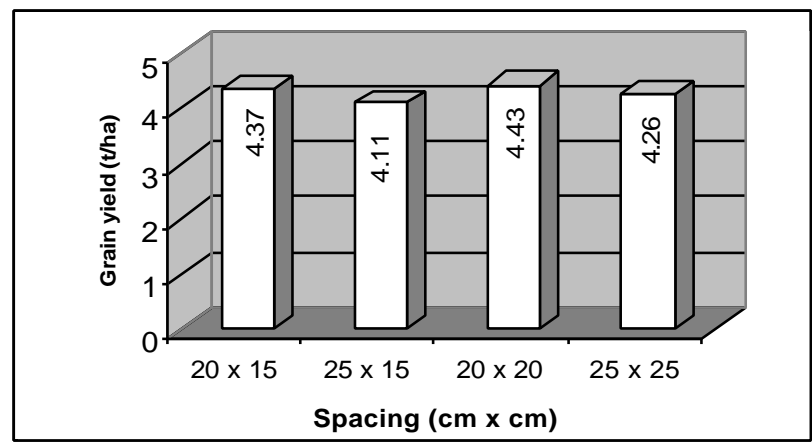

Fig. 3. Grain yield under different spacing

Nitrogen application increased the grain yield over control treatment (Fig. 4). Grain yield obtained from $80,100 \mathrm{~kg} \mathrm{~N} \mathrm{ha}^{-1}$ and LCC-based $\mathrm{N}$ application were comparable but each was significantly higher than $60 \mathrm{~kg} \mathrm{~N} \mathrm{ha}^{-1}$. From the users' point of view, $80 \mathrm{~kg} \mathrm{~N} \mathrm{ha}^{-1}$ would be imperative. The comparable grain yield of LCC-N might be due to inappropriate reference value for this variety. Khan et al. (2004) found higher grain yield in LCC-based N management in rice where thresh hold value for LCC was used 3.5 for transplanted rice. Alam et al. (2004) recommended LCC thresh hold value, 3.5 for transplanted rice for some popular varieties of Bangladesh.

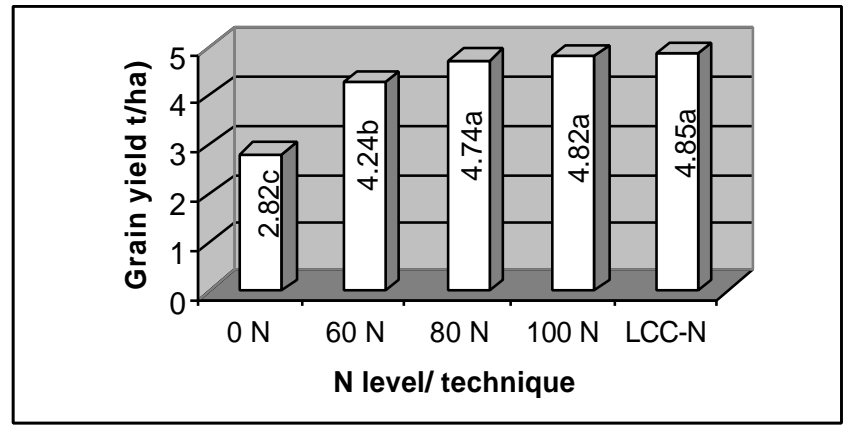

Fig. 4. Grain yield under different $\mathrm{N}$ level and technique 


\section{CONCLUSION}

From the results, it might be concluded that the variety, BRRI dhan44 could be cultivated at wider spacing with $80 \mathrm{~kg} \mathrm{~N} \mathrm{ha}^{-1}$.

\section{LITERATURE CITED}

Alam, M. M., Buresh, R. J., Ladha, J. K. and Khan, A. H. 2004. "Site specific nutrient management (SSNM) for rice: Recommendation and user guide lines". Bangladesh Rice Research Institute, Gazipur-1701. p.14.

BRRI. 1998. Annual report for 1994. Bangladesh Rice Research Institute, Gazipur-1701. pp.10-12.

BRRI. 1999a. Cultivation of Modern Rice (In Bangla). Bangladesh Rice Research Institute, Gazipur-1701. p.26.

BRRI. 1999b. Research Highlights for 1997. Bangladesh Rice Research Institute, Gazipur-1701. p.12.

Elahi, N. E., Khan, A. H., Khan, A. I., Hossain, M. A., Islam, M. R. and Salam, M. A. 2001. Validation and delivery of new technologies for increasing the productivity of flood-prone rice lands of Bangladesh. Research Report presented in IFAD Review workshop held at BRRI, Gazipur on 1-2 June, 2001.

IRRI. 1999. Use of leaf color chart (LCC) for N management in rice. International Rice Research Institute (IRRI), CREMNET Technology Brief No. 2, Los Banos, Philippines. pp.1-4.

Khan, A. H., Khan, A. I. Bose, M. L. and Hossain, M. 2003. Performance of validation and farmers' perception of BR6110-10-1-2 in tidal non-saline zone in Bangladesh. Report presented in the IFAD Annual Planning and Steering Committee Meeting held at Prachin Buri, Thailand held on 20-22 January, 2003.

Khan, A. H., Rashid, M. H., Alam, M. M., Buresh, R. J. and Ladha, J. K. 2004. Nutrient management for intensive rice-based cropping systems: LCC for nitrogen fertilizer management in rice. Paper presented in the workshop on Technology Development, Organized by PETRRA, IRRI and BRRI held on 23-24 May, 2004 at BRRI, Gazipur.

Lourduraj, A. C. and Rajagopal, A. 1999. Effect of irrigation regimes and planting geometry on nutrient availability, uptake of nutrients and grain yield in rice. Madras Agril J 86(7-9), 347-351.

Maske, N. S., Borkar, S. L. and Rajgire, H. J. 1997. Effects of nitrogen levels on growth, yield and grain quality of rice. $J$ Soils and Crops 7(1), 83.86.

Paraye, P. M., Kandalkar, V. S. and Paliwal, A. K. 1996. Effect of split application of nitrogen and plant spacing on lowland bunded rice. Indian J Agron 41(3), 490-492.

Rahman, M. A. and Barua, A. K. 1998. Studies on the effect of spacing on some agronomical characters and NPK concentrations of BR11 Aman paddy. Chittagong Univ J Sci 22(1), 91-95.

Rashid, M. A., Jameel, F., Ishaque, M.and Billah, K. A. 1996. Time of urea incorporation to soil on nitrogen use efficiency in wetland rice soil. Bangladesh Rice $J$ 7(1\&2), 23-26.

Rekhashri, K., Borthakur, M. P., Sarmah, B. N. and Kalita, R. 1997. Effect of planting geometry and levels of fertilizer on yield parameters, yield and uptake of late planted sail rice. J Agril Sci Soc North East India 10(2), 256-258.

Ryong, S.H., SukWean, K., OhDo, K., HeungGyu, P., Yeen, L., TaeDong, P., YongJae, K., Shin, H. R., Kim, S. W., Kwon, O. D., Park, H.G., Lee, Y., Park, T. D. and Kim, Y. J. 1998. Effect of transplanting date, nitrogen rate and plant density on growth and yield of purple rice. RDA J Agr Environ Sci 40(2), 56-62.

Saha, A. and Saha, A. 1998. Effect of planting density on distribution of high density grains in two lowland rice varieties. Flora-and-Fauna Jhansi 4(1), 33-34.

Shrivastava, G. K., Khanna, P. and Tripathi, R. S. 1999. Response of hybrid and popular rice cultivars to different planting geometry. Madras Agril J 86(7-9), 489-490.

Shukla, A. P., Dubey, K. M., Agarwal, S. B. and Dubey, R.K. 1996. Effect of planting geometry and fertility levels on harvest index of transplanted rice. Current Res Univ Agril Sci Bangalore 25(4), 70.

Singh, S. S. 1988. "Principles and Practices of Agronomy". Kalyani Publishers. 1/1 Rajinder Nagar, Ludhiana141008. India.

Wang, S., Cheng, H., Xu, Z., Zheng, X. Y., Yue, C. G., Wang, S. Y., Hao, C., Zhang, X., Xue, Y. Z., Chen, G. Y. and Wang, K. S. 1999. High yielding cultivation techniques of rice cultivar Yujing 8. J Henan Agril Sci 11, 9-11.

Yang, F., Cheng, H. C., Li, W. X., Wen, S. X., Jun, G. X., Yang, F., Hu, C. C., Wang, X. L., Shao, X. W. and Geng, X. J. 2000. Effects of plant density on growth and yield of rice "Jinngda 7". J Jilin Agril Univ 22(4), 18-22. 